\title{
Komitmen Organisasi Karyawan Outsourcing Kabupaten Kudus Ditinjau dari Stress Kerja
}

Iranita Hervi Mahardayani, M.Psi \& Dhini Rama Dhania, M.Si

Fakultas Psikologi Universitas Muria Kudus. Jalan Lingkar Utara Kudus Jawa tengah. Kode Pos 59324 iranita_hervi@yahoo,com

\begin{abstract}
This study aims to determine empirically the relationship between job stress and organizational commitment on outsourced employees in Kudus. The population in this study were outsourced employees in Kudus and the samples were 200 outsourced employees that were selected by accidental sampling technique. Job stress scale and organizational commitment scale were used to collect the data and the result was analyzed using the product moment correlation that was calculated by SPSS 15.0 for windows. The results showed that there was a significant negative relationship between job stress and organizational commitment $(r=-0.648, p<0.01)$.
\end{abstract}

Keywords : Commitment organization, outsourcing, stress work

\begin{abstract}
ABSTRAK
Penelitian ini bertujuan untuk mengetahui secara empiris apakah ada hubungan antara stress kerja dengan komitmen organisasipada karyawan outsourcing di kabupaten Kudus.Populasi dalam penelitian ini adalah karyawan outsourcing di Kabupaten Kudus dengan sampel sebanyak 200 orang yang dipilih dengan teknik accidental sampling.Pengumpulan data dilakukan dengan menggunakan skala stress kerja dan skala komitmen organisasi. Hasil analisis data menunjukkan hubungan negatif yang sangat signifikan antara stress kerja dengan komitmen organisasidengan koefisien korelasi sebesar r:-0,648 dengan p: 0,000 ( $<<0,01)$ ini. Semakin tinggi stress kerja maka semakin rendah komitmen organisasi karyawan outsourcing dan sebaliknya semakin rendah stress kerjamaka semakin tinggi komitmen organisasi karyawan outsourcing.
\end{abstract}

Kata Kunci :komitmen organisasi, outsourcing, stress kerja,

\section{PENDAHULUAN}

Fenomena penggunaan jasa outsourcing oleh perusahaan yang semakin meningkat, menyebabkan perusahaan tidak perlu lagi menyediakan fasilitas dan tunjangan yang berkaitan dengan kesejahteraan karyawan dan keluarganya. Kewajiban tersebut, menjadi tanggung jawab perusahaan outsourcing dan bukan menjadi tanggung jawab perusahaan tempat karyawan tersebut bekerja

Karyawan yang berstatus outsourcing mendapat penghasilan yang berbeda dengan karyawan berstatus tetap akan tetapi tidak memiliki kesempatan dalam pengembangan karir karir diorganiasi. Meskipun demikian karyawan 
outsourcing memiliki tanggung jawab yang sama dengan karyawan tetap, memiliki fasilitas fisik seperti sarana dan prasarana yang berkatiatan dengan pelaksanaan tugasnya sama dengan karyawan tetap dan dituntut produktif dan menghasilkan kualitas pekerjaan yang sesuai standard perusahaan pengguna (Mahardiani dan Pradhanawati, 2013)

Penggunaan karyawan outsourcing memungkinkan perusahaan lebih fokus dalam kegiatan utamanya dan tidak perlu melakukan upaya-upaya lain sebagaimana mengelola karyawan tetap seperti sistem karier, penggajian, pension atau pesangon dan lain sebagainya terkait dengan manajemen sumber daya manusia. Karyawan outsourcing yang tidak sesuai dengan target perusahaan tidak akan diperpanjang kontraknya dan akan dengan mudah mendapat penggantinya dari perusahaan penyedia tenaga kerja. Meskipun demikian, sistem ini merugikan karyawan outsourcing, selain tidak ada jenjang karier, minimnya fasilitas, masa kerja yang tidak pasti, serta terkadang gaji mereka yang telah dibayar oleh perusahaan pengguna dipotong oleh perusahaan induk atau penyedia jasa tenaga kerja sebagai jasa memberi pekerjaan di perusahaan lain tersebut. (Hartono, 2013)

Kondisi yang demikian ini cenderung mempengaruhi sikap kerja karyawan outsourcing antara lain berkaitan dengan komitmen organisasi. Menurut Greenberg dan Baron (1997), komitmen organisasi menggambarkan seberapa jauh seseorang mengidentifikasi dan melibatkan dirinya serta keinginan untuk tetap tinggal di organisasi itu. Pentingnya komitmen organisasi yang dimiliki karyawan berpengaruh pada kinerja karyawan yang pada akhirnya akan mempengaruhi produktivitas organisasi. Komitemen organisasi berhubungan dengan rendahnya tingkat absensi dan intense turn over pada karyawan (Robbins, 1998).

Menurut Luthans (Utami, 2009) komitmen organisasi merupakan sikap yang menggambarkan loyalitas karyawan pada organisasi dan proses berkelanjutan. Karyawan yang memiliki komitmen terhadap organisasi menunjukkan perhatiannya terhadap organisasi dan mendukung keberhasilan serta kemajuan organisasi yang berkelanjutan.Berdasarkan hasilsurvey pada pekerja indonesia yang dilakukan tahun 1993, didapatkan hasil bahwa lebih dari 70\% menyatakan kurangnya loyalitas karyawan terhadap perusahaan dibandingkan tahun 1988 (Darmawan, 2013).

Allen \& Meyer (Robbins, 1998) mengkategorikan komitmen organisasional dalam sebagai berikut:

1. Komitmen afektif (affective commitment) yaitu kelekatan emosional, identifikasi dan keterlibatan dalam suatu organisasi serta keinginan seseorang untuk menetap dalam suatu organisasi karena keyakinan dalam pada nilai-nilai oraganisasi.

2. Komitmen kontinyu (continuance commitment) yaitu komitmen iseseorang terhadap organisasi yang didasarkan pada pertimbangan tentang apa yang harus dikorbankan bila akan meninggalkan organisasi dan idividu memutuskan untuk menetap pada suatu organisasi karena menganggapnya sebagai suatu upaya pemenuhan kebutuhan.

3. Komitmen normatif (normative commitment) adalah perasaan yang mengharuskan untuk bertahan dalam organisasi dikarenakan kewajiban dan tanggung jawab terhadap organisasi yang didasari atas pertimbangan norma, nilai dan keyakinan karyawan.

David (Sopiah, 2008) menyatakan bahwa komitmen karyawan terhadap organisasi dipengaruhi oleh beberapa faktor, antara lain:

1. Faktor personal, misalnya usia, jenis kelamin, tingkat pendidikan, pengalaman kerja, kepribadian, dll;

2. Karakteristik pekerjaan, misalnya lingkup jabatan, tantangan, konflik, peran, tingkat 
kesulitan dalam pekerjaan, dll;

3. Karekteristik struktur, misalnya besar/kecilnya organisasi, bentuk organisasi (sentralisasi/ desentralisasi), kehadiran serikat pekerja;

4. Pengalaman kerja. Pengalaman kerja karyawan sangat berpengaruh terhadap tingkat komitmen karyawan pada organisasi.

Salah satu factor yang mempengaruhi komitmen karyawan terhadap organisasi adalah karakteristik pekerjaan.Karakteristik pekerjaan berhubungan dengan tututan pekerjaan, tantangan, kesulitan dan hambatan pekerjaan yang dialami seseorang dalam aktivitas kerjanya.Persaingan dan tuntutan profesionalitas yang semakin tinggi menimbulkan banyaknya tekanan-tekanan yang harus dihadapi karyawan. Tidak terkecuali pada karyawan outsourcing . Karyawan outsourcing dituntut memiliki kinerja yang baik, menghasilkan produktivitas tinggi baik secara kuantitas maupun kualitas untuk dapat bertahan di organisasi. Disisi lain, ketidak jelasan status, tidak ada jaminan keberlangsungan dan pengembangan karir yang jelas menjadi tekanan lain dalam aktivitas kerjanya. Tekanan yang timbul dan berlangsung terus menerus berpotensi menimbulkan kecemasan.Salah satu dampak yang sangat merugikan dari adanya gangguan kecemasan yang sering dialami oleh karyawan outsourcing di lingkungan kerja adalah stress kerja. Seperti yang diungkap dalam hasil penelitian Astuti (2008) dan Ismar, dkk (2011) yaitu bahwa faktor yang paling tinggi membangkitkan stress kerja pada karyawan outsourcing adalah pengembangan karir.

Stress kerja merupakan suatu keadaan yang timbul dalam interaksi diantara manusia dan pekerjaannya (Beehr dan Newman dalam Wijono 2010). Robbins (2003) mengemukakan stress kerja merupakan kondisi dinamik yang dialami individu dalam menghadapi peluang, kendala, tuntutan yang terkait dengan apa yang sangat diinginkannya dan hasilnya dipersepsikan sebagai tidak pasti tetapi penting. Stres kerja adalah ketegangan atau tekanan emosional yang dialami seseorang yang sedang menghadapi tuntutan yang sangat besar, hambatan-hambatan, dan adanya kesempatan yang sangat penting yang dapat mempengaruhi emosi, pikiran, dan kondisi fisik seseorang Hariandja (2002).

Stres kerja oleh Beehr dan Newman (dalam Rice, 1999) dikategorikan dalam beberapa aspek-aspek yang meliputi :

a. Aspek fisiologis, memiliki indikator yaitu meningkatnya detak jantung, tekanan darah, mudah lelah fisik, kepala pusing, sakit kepala, ketegangan otot, gangguan pernapasan, gangguan tidur, sering berkeringat, dan telapak tangan berkeringat.

b. Aspek psikologis, memiliki indikator yaitu kecemasan, ketegangan, mudah marah, sensitif, kebingungan, gelisah, mengalami tekanan perasaan (depresi), kebosanan, tidak puas terhadap pekerjaan, menurunnya fungsi intelektual, kehilangan konsentrasi, hilangnya kreativitas, tidak bergairah untuk bekerja, merasa tidak berdaya, merasa gagal, mudah lupa, dan rasa percaya diri menurun.

c. Aspek tingkah laku (behavioral), memiliki indikator yaitu penundaan, menghindari pekerjaan, absensi, menurunnya performansi dan produktivitas, pola makan yang tidak teratur, menurunnya hubungan dengan teman dan keluarga, dan tidak berminat berinteraksi dengan orang lain.

Karyawan percaya bahwa perusahaan akan memberikan penghargaan terhadap kinerja yang mereka lakukan dengan baik, namun persaingan berskala global menyebabkan perubahan terhadap kebijakan tradisional seperti jaminan untuk bekerja, senioritas dan kompensasi yang semakin diabaikan perusahaan dapat mengakibatkan penurunan komitmen karyawan. (Darmawan, 2013). Berdasarkan pendapat diatas, dengan adanya sistem outsourcing ini menyebabkan jaminan untuk diangkat sebagai karyawan tetap dengan 
penghasilan yang layak serta kesempatan berkarier semakin diabaikan pula, sehingga komitmen karyawan tersebut dapat menurun semakin tajam.

Padahal komitmen organisasi merupakan salah satu faktor yang mempengaruhi keberlangsungan perusahaan atau organisasi. Seorang karyawan yang memiliki komitmen dapat menjadi lebih bertanggung jawab terhadap pekerjaannya dibanding dengan karyawan yang tidak mempunyai komitmen. Biasanya karyawan yang memiliki suatu komitmen, akan bekerja secara optimal sehingga dapat mencurahkan perhatian, pikiran, tenaga dan waktunya untuk pekerjaanya, sehingga apa yang sudah dikerjakannya sesuai dengan yang diharapkan oleh perusahaan (Handayani, 2013)

Dari kesimpulan diatas dapat diketahui bahwa adanya masalah komitmen organisasi pada karyawan outsourcing, disebabkan karenakan adanya kondisi ketidaknyamanan karyawan outsourcing yang telah disebutkan diatas,dan lebih lanjut akan menimbulkan sebuah kondisi ketegangan secara fisik dan psikis atau lebih dikenal dengan stress kerja., Oleh karena itu penulis tertarik untuk meneliti apakah hubungan antara stress kerjaterhadap komitmen organisasi karyawan outsourcing di Kabupaten Kudus dan berapa sumbangan efektifnya.

\section{METODE PENELITIAN}

Penelitian ini dilakukan dengan menggunakan pendekatan kuantitatif. Populasi dalam penelitian ini adalah karyawan outsourcing di Kabupaten Kudus dengan sampel penelitian sebanyak 200 karyawan yang dipilih dengan teknik accidental sampling. Data dikumpulkan dengan menggunakan skala, yaitu skala komitmen organisasi dan skala stress kerja. Skala stress terdiri dari 21 item dengan koefisien validitas berkisar antara 0,300 sampai 0,581 dan reliabilitas alpha $\left(r_{t}\right)$ sebesar 0,854 . Skala komitmen organisasi terdiri dari 13 item dengan koefisien validitas berkisar antara 0,320 sampai 0,551 dan reliabilitas alpha $\left(r_{t t}\right)$ sebesar 0,788 . Analisis data dilakukan dengan teknik korelasi product moment menggunakan program SPSS 15.0 for windows.

\section{HASIL DAN PEMBAHASAN}

Hasil uji normalitas dengan teknik Kolmogorov - Smirnov menunjukkan sebaran yang normal dari variabel stress kerja dan komitmen organisasi dengan hasil $\mathrm{p}>0,05$. Hasil uji linieritas menunjukkan korelasi antara komitmen organisasi dan stress kerja. Hal ini ditunjukkan dengan hasil dari deviasi linieritas $\mathrm{p}$ $>0,05$ yaitu sebesar 0.538 .

Berdasarkan analisis data, terdapat hubungan negative yang sangat siginikan antara stress kerja dengan komitmen organisasi, dengan rxy sebesar $-0,648$ dengan $p=0,000$ $(p<0,01)$. Hal ini berarti bahwa semakin tinggi stress kerja maka semakin rendah komitmen organisasi karyawan outsourcing, begitu pula sebaliknya semakinrendah stress kerja maka semakintinggi komitmen organisasi karyawan outsourcing. Dengan demikian hipotesis yang diajukan dalam penelitian ini dapat diterima.

Keberhasilan organiasi dalam mencapai tujuan tidak terlepas dari peran karyawan.Peran karyawan dalam organisasi tidak terlepas dari sikap dan perilaku yang ditunjukkan di tempat kerja Salah satu sikap positif karyawan ditempat kerja adalah komitmen organisasi. Komitmen organiasasi merupakan kelekatan emosi, identifikasi dan keterlibatan individu dengan organisasi, serta keinginan untuk tetap menjadi anggota organisasi (Robbins, 2003). Karyawan yang memiliki komitmen terhadap organisasi menunjukkan penerimaan terhadap tujuan dan nilai organisasi, kesediaan untuk memberikan usaha lebih bagi organisasi serta keinginan untuk terus bertahan di organisasi. Karyawan memiliki komitmen yang tinggi akan lebih termotivasi untuk menghindari ketidakhadiran sehingga tentu 
mempermudah tercapainya tujuan organisasi dan memiliki keinginan yang kuat untuk tetap tinggal dalam suatu organisasi sehingga dapat memperkecil turn over serta meningkatkan prestasi kerja. Sebaliknya karyawan yang memiliki komitmen yang rendah menunjukkan tidak adanya semangat bekerja, tingginya absenteeism (tingkat absensi) dan keterlambatan, disiplin kerja yang rendah, menurunnya prestasi kerja dan tidak menutup kemungkinan terjadinya pemogokan kerja, dan turn over (Wayne, Shore \& Liden, 1997)

Salah satu factor yang mempengaruhi komitmen karyawan terhadap organisasi adalah karakteristik pekerjaan. Karakteristik pekerjaan berhubungan dengan tekanan, tantangan , kesulitan dan hambatan yang dialami oleh karyawan yang menimbulkan kesenjangan antara kemampuan dengan tuntutan pekerjaan. Berbagai tekanan yang dialami karyawan berpotensi menimbulkan stres.Hal ini juga dialami oleh karyawan outsourcing.Tututan pekerjaan akan kualitas dan kuantitas yang tinggi, disisi lain tidak adanya jaminan keberlangsungan di dalam organiasi dapat menjadi salah satu stressor yang menimbulkan menimbulkan stress kerja. Stress kerja adalah suatu perasaan yang menekan atau rasa tertekan yang dialami karyawan dalam menghadapi pekerjaannya (Prabu, 1993). Menurut Anoraga (2001) stress kerja adalah suatu bentuk tanggapan seseorang, baik fisik maupun mental terhadap suatu perubahan di lingkunganya yang dirasakan mengganggu dan mengakibatkan dirinya terancam. Gibson dkk (1996) menyatakan bahwa setiap aspek di pekerjaan dapat menjadi pembangkit stress dan karyawan yang menentukan sejauhmana situasi yang dihadapi merupakan situasi stres atau tidak.

Stress yang dialami oleh karyawan dapat berkembang kearah positif yaitu stress dapat menjadi kekuatan positif bagi karyawan untuk bekerja lebih baik. Stres yang pada tingkat tertentu dapat menimbulkan dorongan yang tinggi untuk berprestasi, makin tinggi produktivitas dan efisiensinya (Sunyoto, 2001). Tetapi stress juga dapat berkembang kearah negatif. Berdasarkan penelitian yang dilakukan Randall Schuller (Sutrisna, 2010) stress yang dihadapi karyawan berhubungan dengan penurunan prestasi kerja, peningkatan ketidakhadiran kerja dan kecenderungan mengalami kecelakaan. Menurut Sutrisna (2010) jika banyak diantara tenaga kerja di dalam organisasi atau perusahaan mengalami stres kerja, maka produktivitas dan kesehatan organisasi itu akan terganggu. Stress juga dampak terhadap individu yang ditandai dengan munculnya masalah-masalah yang berhubungan dengan kesehatan. Banyak penelitian yang menemukan adanya akibat-akibat stres terhadap kesehatan seperti jantung, gangguan pencernaan, darah tinggi, maag, alergi, dan beberapa penyakit lainnya

Karyawan yang mengalami stress akan menunjunkkan perubahan pada metabolisme tubuh seperti meningkatnya kecepatan detak jantung dan napas, meningkatnya tekanan darah, timbulnya sakit kepala, menyebabkan serangan jantung (Robbins, 2003). Dengan kondisi tersebut maka karyawan akan merasakan ketidakyamanan, tidak dapat bekerja secara optimal, bahkan beresiko terhadap tingginya kecelakaan kerja. Stress kerja juga berhubungan dengan perubahan emosi, karyawan yang stress akan merasa cemas, gelisah, khawatir. Stress yang dialami karyawan juga menimbulkan rasa tidak puas terhadap pekerjaan, menurunnya fungsi intelektual, kehilangan konsentrasi, hilangnya kreativitas, tidak bergairah untuk bekerja, merasa tidak berdaya, merasa gagal, mudah lupa, dan rasa percaya diri menurun. Hal ini dapat menimbulkan rasa nyaman, konflik dengan rekan kerja, atasan atau pelanggan yang dapat berdampak pada berkurangnya keterlibatan terhadap organiasi, menunda pekerjaannya, penurunan kinreja, tingginya absensi serta keiginan untuk meninggalkan organisasi.

Secara umum, gambaran dari masing- 
masing variebel penelitian ini berdasarkan norma kategorisasi adalah sebagai berikut. Pertama, tingkat komitmen organisasi karyawan outsourcing tergolongtinggi. Hal ini diketahui dari hasil respon subjek pada item dalam skala yang menunjukkan persentase komitmen organisasi terbesar pada tingkat tinggi. Karyawan outsourcing dengan komitmen organisasi di tingkat sangat rendah ada 4 orang (2\%), di tingkat rendah ada 17 orang (8,5\%), di tingkat sedang ada 36 orang (18\%), di tingkat tinggi ada 89 orang $(44,5 \%)$ dan di tingkat sangat tinggi ada 54 orang (27\%). Kedua, Tingkat stress kerja karyawan outsourcing tergolong sangat rendah. Hal ini diketahui dari hasil respon subjek pada item dalam skala yang menunjukkan persentase stress kerja terbesar pada tingkat sangat rendah. Karyawan outsourcing dengan stress kerja di tingkat sangat rendah ada 90 orang (45\%), di tingkat rendah ada 67 orang (33,5\%), di tingkat sedang ada 34 orang (17\%), di tingkat tinggi ada 6 orang (3\%) dan di tingkat sangat tinggi ada 3 orang $(1,5 \%)$.

Berdasarkan hasil data di lapangan diketahui bahwa bahwa komitmen organisasi karyawan outsourcing di Kudus tergolong tinggi dan stress kerjanya tergolong rendah. Data tersebut berbeda dengan dugaan awal yang menyatakan bahwa karywan outsourcing memiliki komitmen organisasi yang cenderung rendah. Berdasarkan hasil wawancara dengan beberapa karyawan outsourcing di Kudus, diperoleh hasil bahwa karyawan menunjukkan sikap nerimo ing pandum (terima apa adanya). Kondisi yang dialami karyawan outsorcing saat ini sudah cukup membuat mereka bersyukur. Mereka juga beranggapan bahwa bekerja adalah ibadah, artinya jika manusia mau bekerja dan berusaha keras untuk menghidupi diri sendiri dan keluarganya, akan dengan sendirinya hidup tentram dan damai dalam masyarakat. Perbedaan ini dimungkinkan terjadi karena terbatasnya jumlah subjek wawancara yang dilibatkan dalam penggalian data kualitatif, sehingga dimungkinkan tidak mewakili keseluruhan subjek.

Berdasarkan hasil analisis data diketahui besarnya pengaruh stress kerja dengan komitmen organisasi tampak pada besarnya sumbangan efektif sebesar 41,9\%, berarti masih ada 58,1 $\%$ faktor lain yang mempengaruhi komitmen organisasi.

\section{SIMPULAN}

Berdasarkan hasil penelitiandapat disimpulkan bahwa ada hubungan negative yang sangat signifikan antara stress kerja dengan komitmen organisasi pada karyawan outsourcing. Semakin tinggi stress kerja maka semakin rendah komitmen organisasi karyawan outsourcing, begitu pula sebaliknya semakinrendah stress kerja maka semakintinggi komitmen organisasi karyawan outsourcing. Stress kerja memberikan sumbangan efektif sebesar 41,9\% terhadap komitmen organisasi, berarti terdapat 58,1 \% faktor lain yang mempengaruhi komitmen organisasi. Bagi penelitian selanjutnya diharapkan dapat mempertimbangkan faktor - faktor lain selain stress kerja yang mungkin berpengaruh terhadap komitmen organiasasi. Selain itu penelitian selanjutnya hendaknyamemperhatikan pemilihan subjek wawancara yang akan digunakan dalam pengambilan sehingga dapat mewakili keseluruhan populasi. Saran bagi perusahaan atau organisasi hendaknya membuat kebijakan dan atau meninjau kembali kebijakan kontrak kerja outsourcing berkaitan dengan aspekaspek kerja yang dapat menimbulkan stress, mengingat tugas dan tanggungjawab karyawan outsourcing yang sama dengan karyawan tetap.

\section{DAFTAR PUSTAKA}

Astuti, SD. 2008.Persepsi Karyawan Outsourcing atas Faktor-Faktor yang 
Membangkitkan Stress Kerja pada call center PT “X” Jakarta Pusat. Skripsi. Universitas Indonesia

Andaryani,M. 2006. Pengaruh Konflik Peran Dan Stress Kerja Terhadap Keinginan Berpindah Dengan Komitmen Organisasi Sebagai Variabel Intervening (Studi PadaAkuntan Publik Di Joglosemar) . Skripsi.http:// dglib.uns.ac.id

Anoraga, P. 2001. Psikologi Kerja. Jakarta: PT Rineka Cipta

Baron, R.A. dan Greenberg, J. (1990).Behavior in Organization- Understanding and Managing the Human Side of Work. $3^{\text {rd }}$ edition

Darmawan. D. 2013.Prinsip-prinsip Perilaku Organisasi.Surabaya: Pena Semesta

Dhania, DR. 2010. Stres Kerja Buruh Rokok di Kota Kudus.Jurnal Sosial Budaya Universitas Muria Kudus. Volume 3. No. 2

Felisa.2011. Pengaruh Outsourcing Dan Komitmen Organisasional Terhadap Kinerja Karyawan.Tesis.Universitas $\mathrm{P}$ a d j a j a r a n . ht t p : / / repository.unpad.ac.id

Gibson dkk. 1996. Organisasi. Editor: Lyndon Saputra. Jakarta: Binarupa Aksara

Handayani.2013.Pentingnya Komitmen dalam Suatu Perusahaan atau Orga n i s a s i.h t t p : / / edukasi.kompasiana.com

Hariandja, M TE, 2002, Manajemen Sumber Daya Manusia, Jakarta :Grasindo

Ismar,R.Amri Z.Sostrosumihardjo. 2011.Stress Kerja dan Berbagai Faktor yang berhubungan Pada Pekerja Call
Center PT "X” di Jakarta.Majalah Kedokteran Indonesia.Volume 61. No.1.

Mahardiani Y.dan Pradhanawati.A. 2013. Pengaruh Stres Kerja Dan Lingkungan Kerja Fisik Terhadap Kinerja Karyawan Outsourcing Pada Pt. Bank Jateng Cabang Koordinator dan Cabang Pembantu Wilayah Kota Semarang. Jurnal Administrasi Bisnis.Volume 2, No.1

Mangkunegara, A dan Anwar Prabu. 2005.Perilaku dan Budaya Organisasi. Bandung: PT Refika Aditama

Prabu A. 1993. Psikologi Perusahaan. Bandung: Trigenda Karya

Rice, P.L.1999. Stress and Health (3rd ed). California: Brooks Cole Publising Company

Robbins, S P. (2003).Perilaku organisasi.Jakarta :PT. Indeks Kelompok Gramedia

Rulestri , S dan Eryanto H.2013.PengaruhKonflik Peran Dan Stres Kerja Terhadap Komitmen Organisasi Di Rumah Sakit Tk Iv Salak, Bogor. EconoSains. Volume 11, Nomor 2

Sunyoto, A. 2001.Psikologi Industri dan Organisasi. Jakarta: Universitas Indonesia

Sutrisna.E. 2010.Pengaruh Stres Kerja Terhadap ProduktifitasAnggota Organisasi.Universitas Sultan Agung Tirtayasa.

Sopiah, 2008, Perilaku Organisasi, Yogyakarta: Penerbit Andi,

Utami ,I dan Bonussyeani, NES,.2009.Pengaruh Job insecurity, kepuasan kerja dan 
komitmen organisasional terhadap keinginan berpindah kerja. Jurnal Akuntansi dan Keuangan Indonesia. Volume 6. Nomor 1

Wayne, S.J; Shore,L.M;Liden, R.C. Perceived of Organizational Support and Leadre Member Exchange:A.Sosial Exchnge Perspective. Accademy of Management Journal. 1997.Vol.40. No.1 83-111

Wijono.S.2010. Psikologi Industri dan Organisasi.Jakarta: Kencana 